\title{
Sustainable Development and Restoring the Landscape after Coal Mining in the Northern Part of the Czech Republic
}

\author{
Jaroslava Vrablikova, Eliska Wildova, Petr Vrablik \\ Faculty of Environment, J. E. Purkyne University in Usti nad Labem, Usti nad Labem, Czech Republic \\ Email: Wildova.Eliska@gmail.com
}

How to cite this paper: Vrablikova, J., Wildova, E. and Vrablik, P. (2016) Sustainable Development and Restoring the Landscape after Coal Mining in the Northern Part of the Czech Republic. Journal of Environmental Protection, 7, 1483-1496. http://dx.doi.org/10.4236/jep.2016.711125

Received: September 5, 2016

Accepted: October 18, 2016

Published: October 21, 2016

Copyright () 2016 by authors and Scientific Research Publishing Inc. This work is licensed under the Creative Commons Attribution International License (CC BY 4.0).

http://creativecommons.org/licenses/by/4.0/

\section{(c) (i) Open Access}

\begin{abstract}
Coal mining has an impact on the countryside and landscape where the exploitation of the mineral occurs, particularly with regard to the way it is mined, the technology used, the surface area, and the shape of the coalfield and extent of mining. The impact of mining, which is predominantly negative, is gradually being eliminated today in accordance with applicable laws by applying knowledge and experience and with the help of a variety of reclamation and revitalization activities. The newly created landscape gives the area new value and opportunity for use. The process of restoring a landscape after coal mining should be primarily guided by the principle of sustainable development to ensure that a balance of the social, economic and environmental aspects is achieved. This article discusses the theoretical basis of the individual possibilities for restoring the landscape in such a way that the anthropogenic formations caused by coal mining are best incorporated into the surrounding landscape and likewise meet the social and economic needs of society. A model area can be found in the northern part of the Czech Republic that has been scarred by coal strip mining for nearly 200 years, but the adverse effects on the landscape have been successfully smoothed over by reclamation methods.
\end{abstract}

\section{Keywords}

Coal Mining, Reclamation, Revitalization, Sustainable Development, Land Resources

\section{Introduction}

The biggest anthropogenic burden in the Czech Republic can be found in the northern part of the country. For nearly 200 years, this area has been considerably affected by intensive mining and industrial activities. The area is a typical industrial region, which at 
the end of the 1980s was among the most devastated in Central Europe the so-called "black triangle" (Figure 1). The environment in the surrounding basin has also been severely affected by the mining of brown coal and its use in power plants and industry. Up to 116 villages have disappeared as a result of the strip mining of coal. The transformation of the Czech economy has gradually led to an attenuation of mining, industrial production and a reduction in the intensity of agricultural production in North Bohemia, which has created other specific regional disparities. In 2015, the Czech government approved a partial suspension of limits on mining. The main argument for the suspension was the high unemployment rate in the region, which increased with the decrease in mining. The suspension of these limits shifted the integration of the anthropologically affected region into its surroundings. It is because this region is home to a major portion of the population that an attempt is being made to integrate it into the surrounding landscape and to ensure a permanently sustainable form of management here. This issue is being dealt with through a project called "Sustainable Forms of Management in Anthropologically Affected Areas" at the Faculty of Environment at the University of Jan E. Purkyne in Usti nad Labem. In cooperation with the Research Institute for Brown Coal in the city of Most, this faculty has been intensively involved in renewing the landscape after coal mining, from both the theoretical and practical points of view, and their graduates receive valuable knowledge for preserving sustainable development in the region and society.

\section{Materials and Methods}

\subsection{Sustainable Development}

Sustainable development can be evaluated from various viewpoints. In this article, sustainable development is evaluated from three basic, intersecting viewpoints (Figure 2):

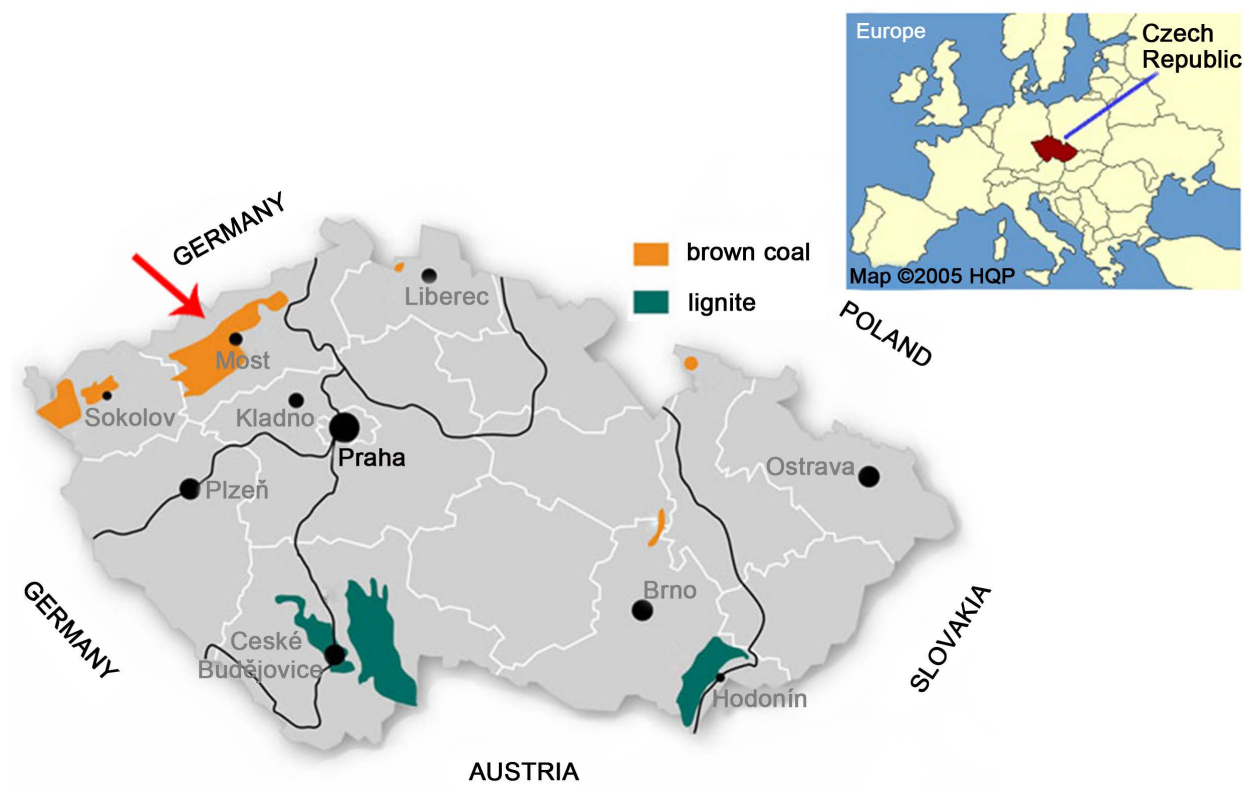

Figure 1. Deposits of brown coal and lignite in the Czech Republic [1]. 


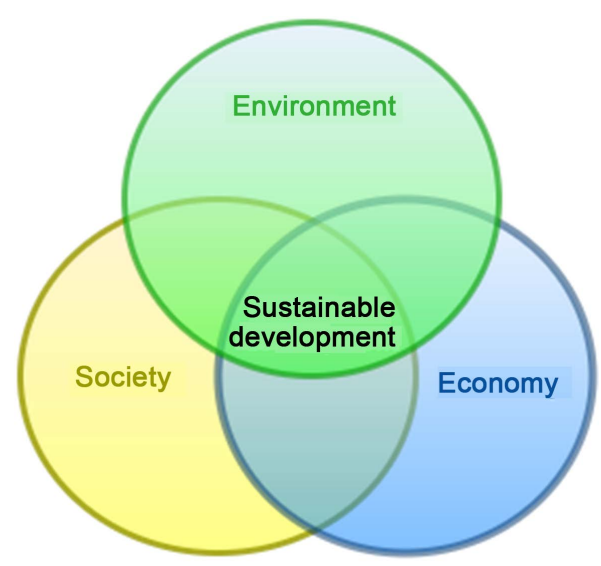

Figure 2. The conjunction of required changes for the application of the TUR concept.

a) Ecological viewpoint,

b) Biophysical and socioeconomic viewpoint,

c) Political viewpoint.

Ecological viewpoint of sustainable development

One of the most important of the viewpoints is ecological because it is closely associated with the structure and workings of ecosystems like the basic functioning units of nature. In evaluating the ecological aspects of sustainable development, biodiversity, ecosystems, healthy ecosystems, the management of ecosystems, and fertility of ecosystems occupy important positions.

The ecological approach to caring for the region and its sustainable development should safeguard:

> The appropriate ecological quality of the area (stability, capacity, balance, durability, etc.) by preserving adequate surface areas for open vegetation, forests, meadows, pastures and water surfaces.

$>$ The protection and reasonable use of natural resources, primarily soil, water and wood resources.

$>$ The protection of the immediate human environment. This involves arranging anthropic, semi-natural and natural elements to ensure that the main hygienic, health and psychological requirements of people are secure in a healthy environment.

\section{Biophysical and socioeconomic viewpoint of permanent sustainability}

From the socioeconomic viewpoint, it is important in terms of sustainable development to examine the processes that provide social, economic and environmental balance throughout the world. This means the creation of a mutually linked structure for decision-making based on communities that enable people to coordinate their individual actions in a way that does not destroy their common wealth. The moral view of sustainability means exploring difficult questions such as the values of future generations or the value of aesthetic beauty.

These biophysical and socioeconomic factors are important for achieving permanent sustainability on our planet: 
The complete recycling of material.

$>$ The transition to a permanently sustainable worldwide energy system.

$>$ The stabilization of, or decrease in, the human population.

$>$ Closing the gap between developed and developing nations of the world.

> Creating a decision-making structure based on communities that enable broad, coordinated involvement in decisions reached about the planet's common resources.

$>$ Changes in the relationship between economic and ecological systems.

\section{Political viewpoint of permanent sustainability}

The problems of permanent sustainability should be addressed not only by environmentalists, but also by politicians. Sociologists, philosophers, political scientists and economists must work together to look for political, economic and legal mechanisms that would make it possible to address growing ecological problems.

The permanent sustainability of life requires a more complex legal treatment of environmental protection than what exists today and mainly a broader commitment to environmental policies. It requires cooperation between politicians and experts in the field. Unlike shortsighted conventional policies that approve the exploitation of natural resources and concentrate on regulating the life of cultural ecosystems, a new ecological policy must be founded on different principles. The possibilities of most nation states are basically fewer than the needs of effective intervention against global risks. First and foremost are the effects of climate change, the disruption of the ozone layer, and the problem of supplying drinking water in many parts of the world. A country that is unable to protect its population from global ecological problems may lose its authority, and that casts doubts on the legitimacy of the demands it makes on its population. The state's activities should more vigorously promote the renewal of an acceptable environment and avoid inflicting new damage on the environment [2].

The biggest global demand for sustainable development is the eradication of poverty in all forms and dimensions, including extreme poverty. All countries and all parties involved, working in alliance with each other, should make this plan happen. Humanity must be free of the tyranny of poverty. We must be resolved to accept changes that are necessary for the planet's transition toward a path to sustainable development.

Figure 3 shows 17 basic goals of sustainable development divided into 169 tasks that demonstrate the scope and ambition of this new agenda for world development until 2030, adopted in New York in September 2015.

\subsection{Renewing the Landscape after Coalmining}

\section{The effects of mining and dealing with them}

The encroachment of mining on the landscape is represented by a major disparity in coalfields, particularly in the strip mining of brown coal. This encroachment was enhanced in the second half of the 20th century, when mining was concentrated in larger territorial units where giant opencast mining was employed. So far, more than 3.7 billion tons of coal has been mined here. 


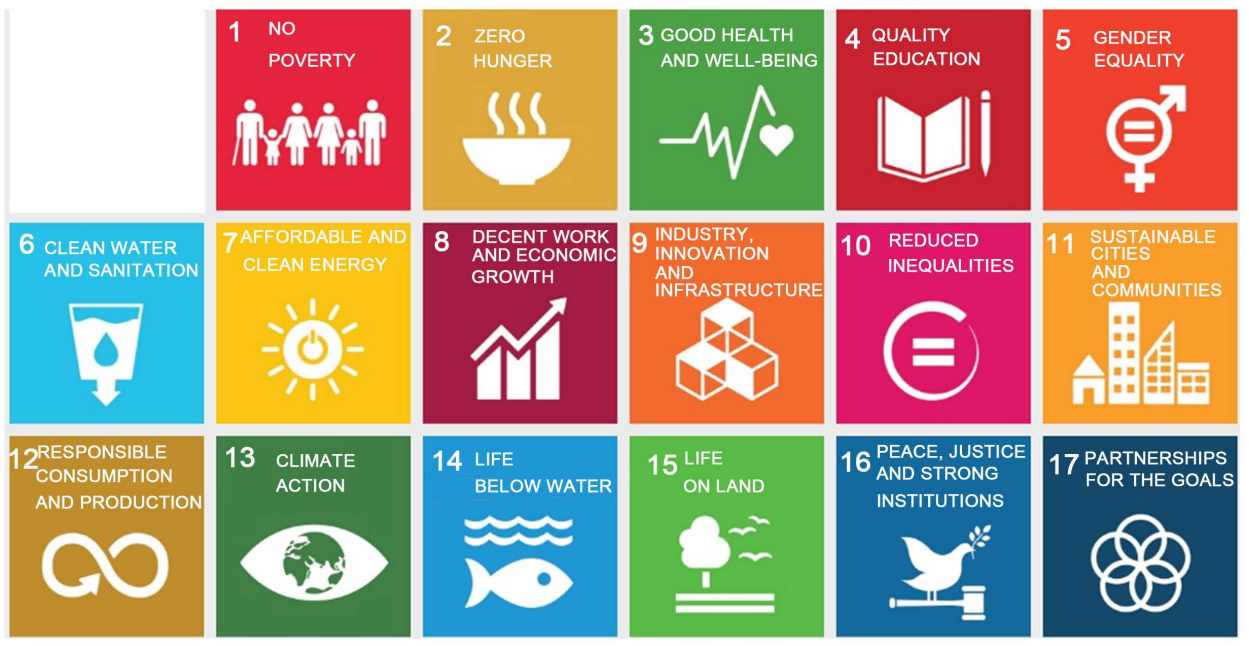

Figure 3. The 17 basic goals of sustainable development [3].

To take the examples of the Chomutov, Most, Teplice and Ústí nad Labem districts, this involves a region that accounts for more than $76 \%$ of all coal mining and produces more than $35 \%$ of electricity in the Czech Republic. The majority of the encroachments on the environment have had an impact on the landscape, manifested by, e.g., contaminated soil, water, the atmosphere, a drop in water tables and sources for drinking water, a decrease in the diversity of plant and animal life, and a host of other impacts.

The prerequisites for the reclamation of the region up until the end of mining were created while mining was being carried out. Reclamation did not mark the end of mining but is rather a structural part of it. It addresses natural subsystems (rocky environments, soil, water, atmosphere and climate, flora, fauna, ecosystems), as well as the renewal of components desired by society (parks, playgrounds, sports venues, gardening plots, suburban recreational zones, lakes and water surfaces).

\section{Theoretical viewpoint of reclaiming the landscape}

The following terms are also associated with restoring the landscape after mining:

\section{Reclamation of the landscape:}

-Human activity focused on renewing the natural features and values of a landscape spoiled by man,

-Recultivating debased land (e.g., after mining of mineral raw materials) in order to return it to agricultural production or afforestation [4].

\section{Melioration of the landscape:}

-Restoring the desired features of a degraded landscape,

-Set of measures of various types focusing on modifying the natural environment to effect better use of it [4].

\section{Rehabilitation of the landscape:}

-Returning it to a state of ecological stability and improving its aesthetic qualities,

-Returning something to its original state, e.g., the landscape [5].

Optimization of the landscape:

-Searching for a socially optimal degree of destabilization in comparison with the 
natural state; this state suffices for meeting all our needs without compromising the regulatory and regenerative processes in the landscape,

-Searching for the best possible options for managed events, decisions and procedures [5].

\section{Reconstruction:}

-Reconstruction of natural geobiocenoses,

-Returning natural features, restoring them to their original form.

\section{Remediation:}

-The goal is to renew the natural features of soil polluted by industrial activity.

\section{Regeneration:}

-This means the ability of an organism to renew cells, organs or entire parts of the body, or even landscape segments,

-This generally involves returning something to its original state, e.g., the land [4].

\section{Redevelopment:}

-Cleaning up, remedying a bad situation. In connection with mining activities, this term is used more for adapting the stability of slopes, overlapping a coal seam or the bottom of a quarry.

For the term recultivation or reclamation, the interpretation is given in relation to agriculture as "recultivating neglected, destroyed or damaged soil" for the purpose of returning it to agricultural production or afforesting it. A broader meaning of the term recultivation is given as a "set of various measures and treatments for reclaiming soil degraded and devastated by natural or human activity, contributing to the restoration of the productivity of the landscape, its natural features as a whole, i.e., all of its natural components." Based on the aforementioned effects of deterioration, a set of measures should follow that contribute to restoring the productivity and functionality of the landscape, i.e., the recultivation process.

The ecological interpretation characterizes recultivation as a human activity focused on renewing the natural features and values of a landscape disturbed by humans and associated with putting that disturbed landscape back into natural balance.

The greatest proportion of recultivated areas in the Czech Republic are those after mineral mining (the strip mining and underground mining of coal, dumps and heaps, tailings ponds, mined peat bogs, areas after the mining of stone, gravel, brick and ceramic materials). Also important are the share of landfills, depositories for waste products (fly ash, ash, slag, etc.) and sludge; all these recent formations must likewise be recultivated. The problem of North Bohemia is especially associated with the strip mining of brown coal.

A remedy for anthropogenic activities consists, after mining, of carrying out recultivation, an eco-technical phase, but also in the subsequent revitalization of the area, which is supposed to lead to resocialization, i.e., the return of people to a previously afflicted landscape.

\section{Methods of renewing the landscape after coal mining-reclamation}

The recultivation of the landscape is classically divided into four main methods: 
These are agricultural recultivation, the result of which is farmland (arable, permanent grasslands, orchards, gardens and vineyards).

$>$ The most extensively used method in the model area is forestry recultivation, with the appearance of productive forests (traditional vegetation or fast-growing trees for energy usage), special-purpose forests (soil conservation, hydrological, agro-meliorative, climate, scattered vegetation, etc.).

> Also represented is hydrological recultivation, which includes stagnant water, flowing water, and wetlands. At present, this method is most effective as part of recultivating the pits left behind after the strip mining of coal.

$>$ So-called other forms of recultivation are also important for people. This method develops new paths, tree-lined alleys, and also places for leisure activity, parks, garden colonies, sports venues, etc.

\section{Phases of the recultivation process}

The recultivation process is divided into four phases:

> The preparation phase optimizes the entire process. In this phase, territorial planning documentation is processed, which addresses the commencement and method of mining, as well as the methods of minimizing and smoothing over the damage after mining,

> The mine-technical phase has a preventive character, addressing technically feasible and economically tolerable conditions for subsequent recultivation activities (locating waste fills, heaps, dumps, the method of shaping mining spaces, any overburden elimination work, etc.),

> The biotechnical phase includes technical and biological procedures that eliminate the negative impacts of mining. The technical work includes shaping the formation and contours of reliefs, backfills of fertile and potentially fertile soil substrates, modifying hydric and runoff conditions in the area, the technical stabilization of slopes and a system of erosion control measures, furthering the construction of roads that make reclaimed areas accessible, and so on. Biological work is a collection of forestry and agro-technical work. This principally involves establishing and maintaining green areas, which are dependent on the type of recultivation and target cultures (agricultural, forestry, landscape gardening, natural types of communities, etc.),

$>$ The post-recultivation phase is associated with handing over recultivated land to its future users and owners [6].

In the preparatory and realization phase, recultivation companies apply their knowledge of biological (landscape ecology, biogeography, geobiocenology, applied biologyagriculture, forestry, horticulture), hydrological, geological, pedological and eco-technical sciences (Figure 4).

\section{Results and Discussion}

\subsection{The Effects of Mining on Land Resources in the Czech Republic and in the Model Area}

Agricultural land resources form the basic natural wealth of the Earth, an irreplaceable 


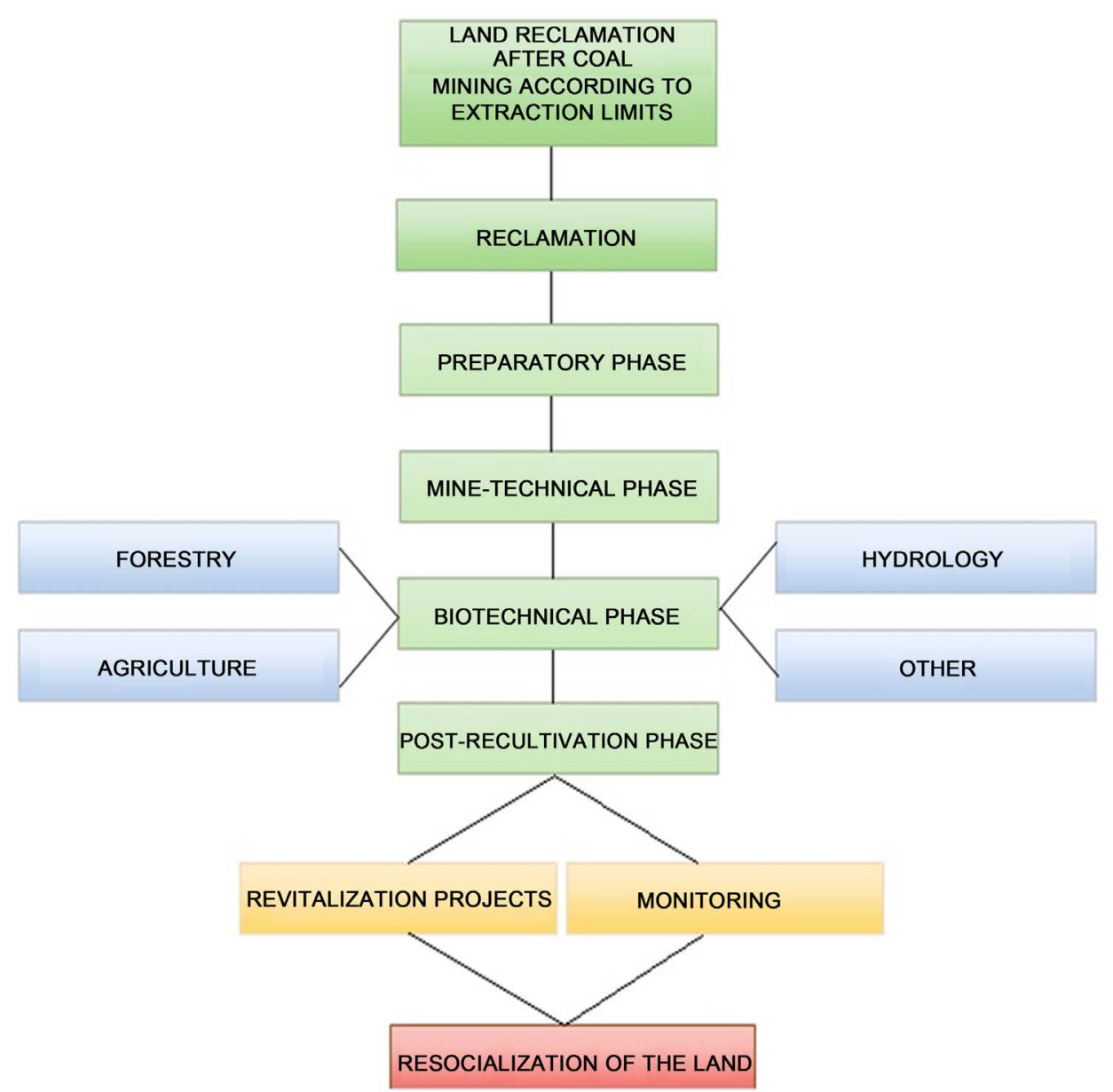

Figure 4. The procedure for land reclamation after coal mining.

means of food production, and one of the principal components of the environment. Protecting agricultural land resources, improving them and using them in a rational way are activities that also encompass the protection and betterment of the environment. The various categories of agricultural land are divided into farmed land, which consists of arable land, hop fields, vineyards, gardens, orchards, grassland, and soil, which are left for future agricultural uses.

Land resources as a whole can be further divided into woodland, water areas and developed land. A mining area is classified among "other" areas, which include all land not listed in the previous categories. These include roads, highways, railroad tracks, landfills and others.

The coverage of farmland in the area affected by coal mining underwent radical shrinkage between 1970 and 1990, when a more intensive method of extracting brown coal was used. Between 1990 and 2014, there was little annual acquisition of agricultural land resources. The last two years saw insignificant growth of agricultural land here by approximately 200 ha. The decreasing trend in the coverage of agricultural land during the mining boom period in the Czech Republic was very similar overall. Nevertheless, after the stabilization of mining, there occurred an alarming nationwide shrinkage in 
agricultural land resources on an annual basis by more than 4000 ha (Figure 5). This was primarily caused by a boom in constructing residential zones in and around large agglomerations and manufacturing and assembly halls.

The opposite development has been logically recorded in case of the coverage of other areas, which include quarry mining areas and their adjacent anthropogenic formations (dumps). The major growth in other areas in the model area of North Bohemia in the boom times of mining brown coal is currently being replaced by a gradual drop, particularly thanks to the winding up of reclamation, which is integrating despoiled areas back into the surrounding landscape. The overall coverage of other areas in the country continues to expand due to growing transport infrastructure (Figure 6).

\subsection{Restoring the Landscape in the Model Area}

The concept of landscape restoration, revitalization, has been an often-discussed issue of late. In the broader sense, this concept refers to all activities, including socioeconomic activities that are associated with improving the quality of the environment in areas adversely influenced by mankind.

Addressing a specific location needs to be subordinated to complex integration into the surrounding landscape. All environmental problems and the relationships between individual components need to be addressed in a complex manner. A specific location should be able to fulfill an ecological function separately. Proposed revitalization mea-
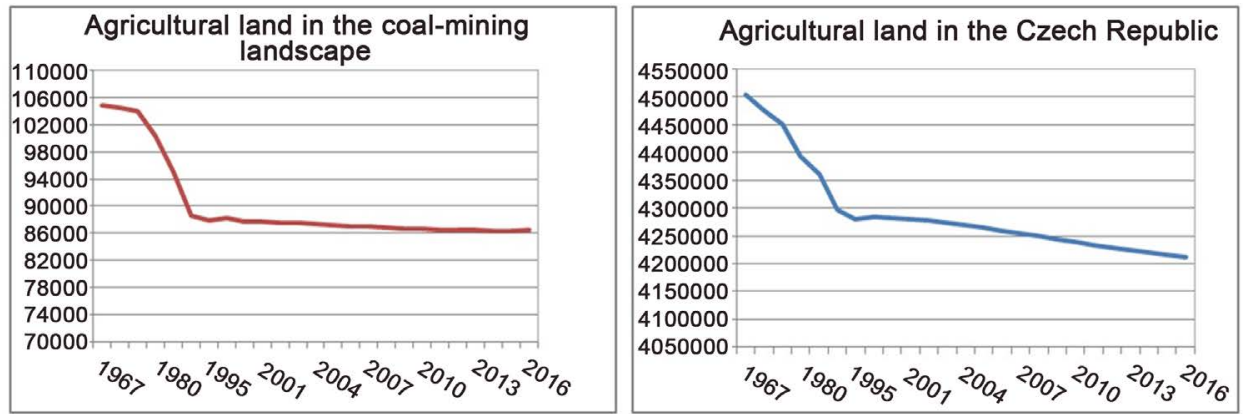

Figure 5. The development of agricultural land in the mining region and in the Czech Republic between 1967 and 2016 in hectares [7].
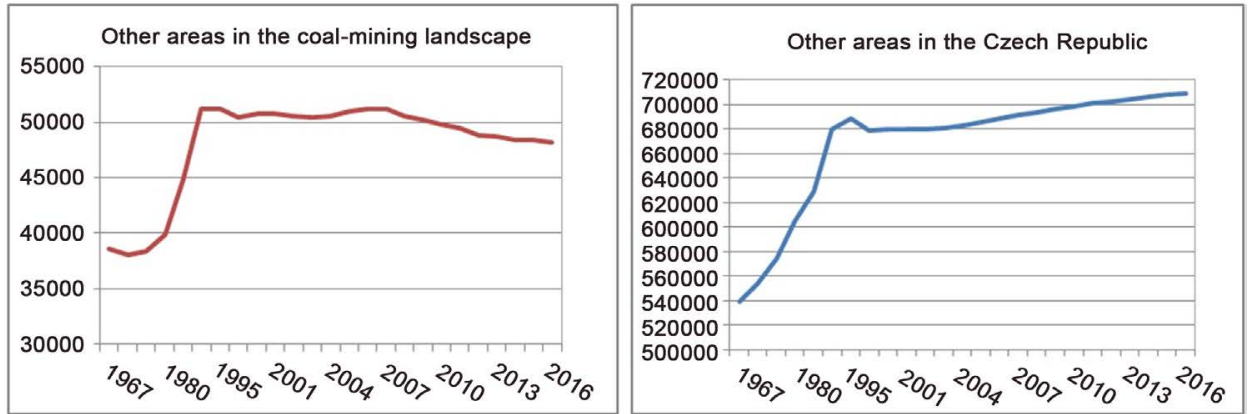

Figure 6. The development of other areas in the mining region and in the Czech Republic between 1967 and 2016 in hectares [7]. 
sures must be feasible, and their effects must be acceptable to society. In addition to the ecological integration of the landscape, it is essential to focus on the requirements of society and adhere to the principles of the integrated management of the region.

Even though the completion of reclamation has proceeded in recent decades at a tempo of one to several thousand hectares per decade, the results have been very limited in terms of the effectiveness of the workings of ecosystems, mainly due to the disrupted water regime of the recultivated landscape. The mining of coal and subsequent renewal of the area and recultivation are connected to a pronounced change in the landscape. This shows in the official statistics of the data related to land resources [8].

\section{Development and structure of recultivation}

The following images show the results of recultivation during the period from 1950 to 2014 (completed recultivation) and the prognosis for further development until the likely end of mining and reclamation (respecting the valid natural limits of mining).

The greatest share in reclamation that is under way or was completed during the period from 1950 through 2014 is represented by forestry recultivation of 7772 ha (45\%). Further down the line, conversely to previous years, there is other recultivation covering 4410 ha (26\%). The coverage of other recultivation is becoming permanent thanks to the areas created adapting very well to society, and their resocialization has been quicker than, for example, agricultural recultivation (3557 ha-21\%), which is gradually losing favor mostly due to the complex process of reclaiming soil. Meanwhile, a smaller share is represented by hydrological recultivation (1479 ha-8\%), which will gradually grow, mainly through flooding the pits left behind in strip-mining quarries (Figure 7 and Figure 8).

The above statistical overviews prepared in the categories up until completed recultivation, recultivation currently under way and moreover with a perspective on the total extent of reclamation in the Most basin following the termination of mining shows that:

\section{Recultivation completed and under way in the Most \\ basin [\%]}

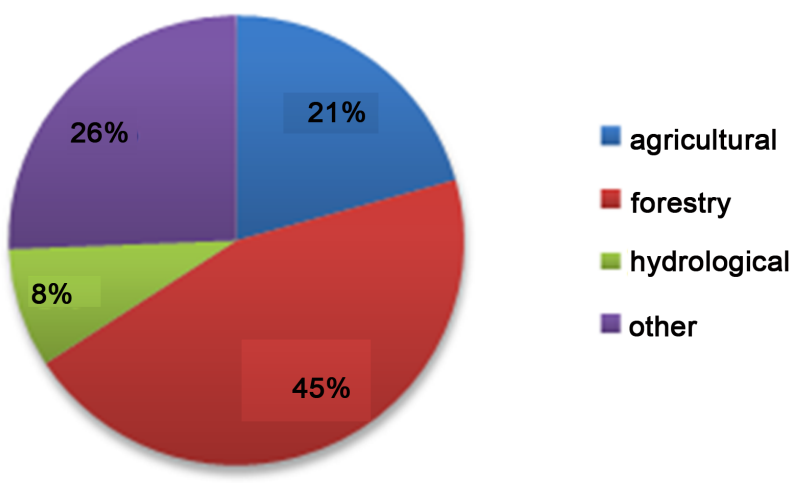

Figure 7. The percentage of recultivation completed and under way until 2014. 
Recultivation completed and under way in the Most basin in 2014 [in hectares]

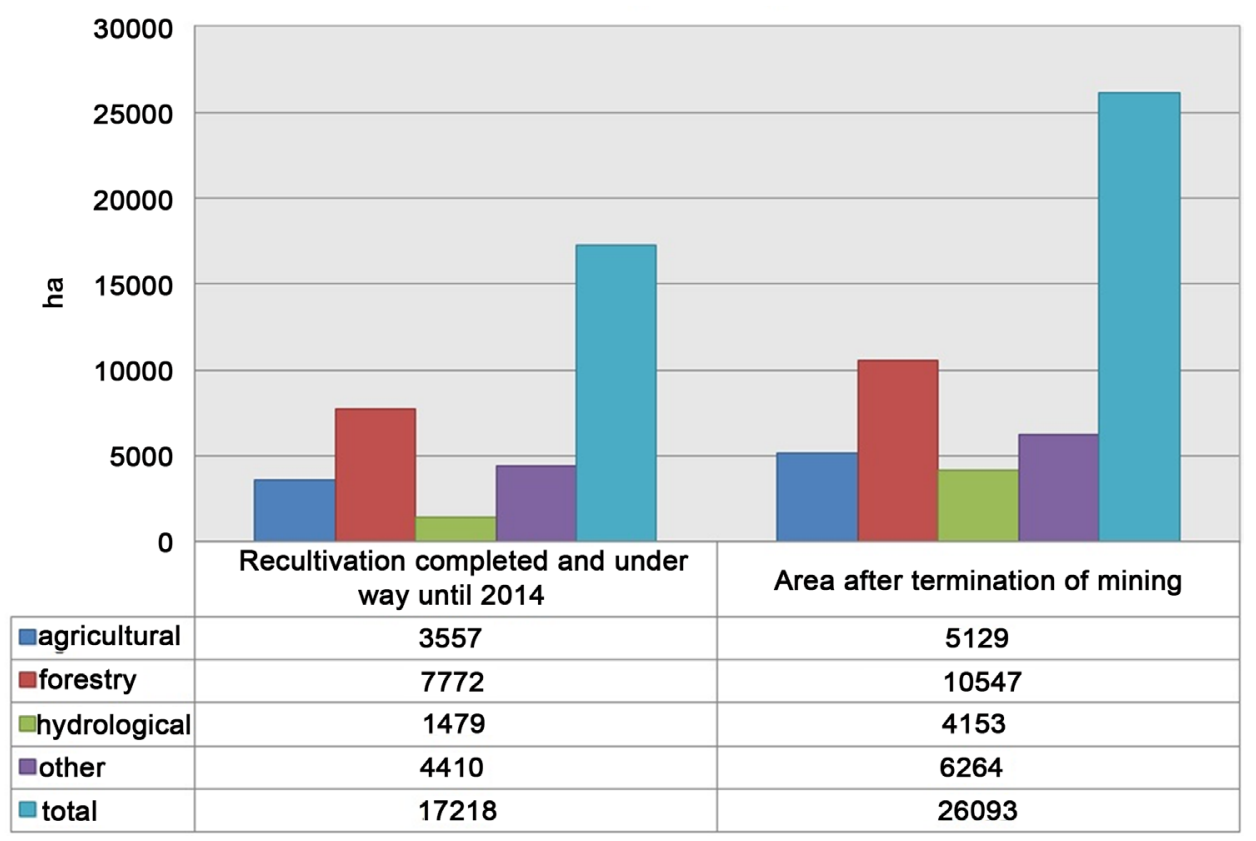

Figure 8. Recultivation of the Most basin.

The greatest attention so far has been paid to forestry reclamation because woodland ecosystems demonstrate the greatest values of ecological stability and have the most expressive positive effect on the character and effectiveness of the environment. The prognosis therefore suggests this will continue even in the future.

$>$ Thanks to a suitable climate, irrigation possibilities and the considerable availability of salvaged topsoil, agricultural reclamation is also under way to a commensurate extent. Feeding the population is and will be at the forefront of national interests. Agricultural land is not only an important component of the environment, but is also the basic means for producing food.

$>$ Water-management forms of reclamation have so far not achieved a greater presence due to the considerable work in progress on brown-coal quarries. Proportional to mining out the mining areas, however, their share will increase thanks to the possibility of using abandoned quarries. This reclamation concept is based on the irreplaceable function of water, as well as components of ecological, social and economic structures.

The relatively high representation of reclamation methods categorized as "other" is due primarily to the fact that urbanization accounts for a significant area, where $80 \%$ of the inhabitants live in cities with more than 10,000 people. This fact stimulates the need to address recultivation in the vicinity of settlements with the creation of a suburban environment that is attractive for leisure activities.

The entire strategy for reclaiming the basin under the Krušné Mountains is based, in the long term, on the real possibilities in this area for creating conditions for this region to become, in its post-mining phase, a valuable resort area, prepared not only 
for leisure-time activities, but also for a manufacturing capacity that is ecologically tolerable and sound.

This concept also respects the probability of possible warming. If there is adequate water and woods in the region, the right conditions will arise here not only for housing and recreation, but also for applying intensive, conventional and specially oriented agricultural production (e.g., local fruits and vegetables) [6].

We can consider the former Vrbenský quarry - the Matylda segment-as a successful example of recultivation. The abandoned quarry was flooded, the surrounding heaps were wooded over, and an in-line track and walkways were built around the lake. Documentary photographs were taken in 1968 and 2005 (Figure 9 and Figure 10).

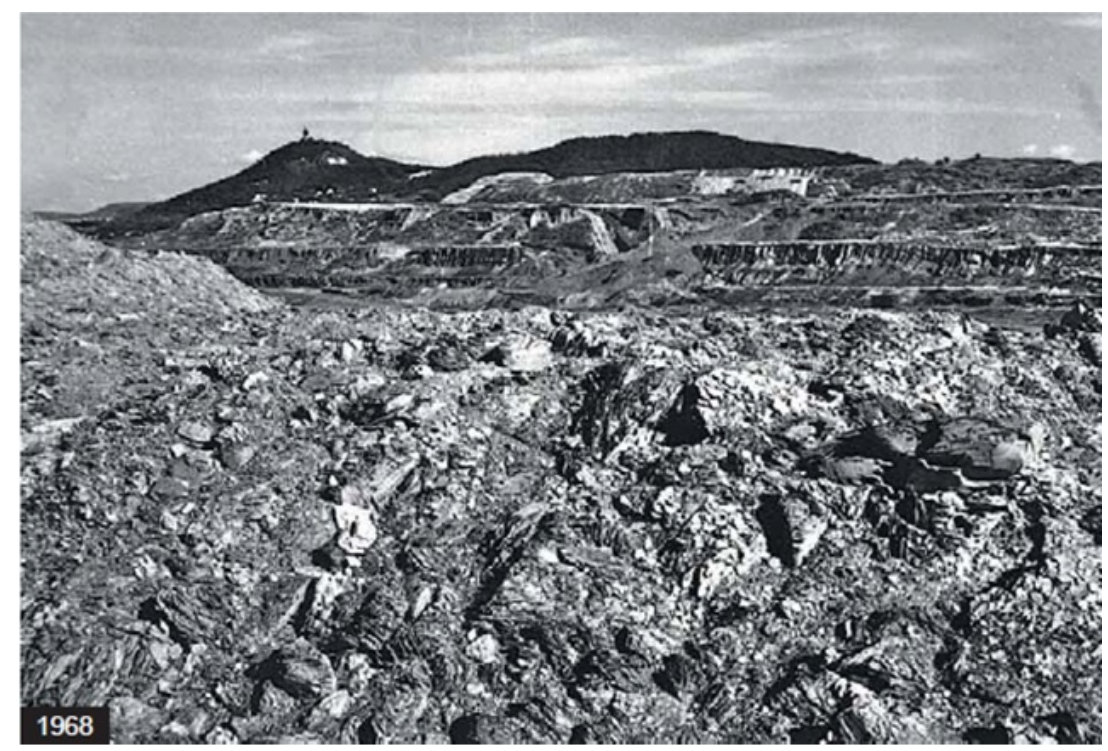

Figure 9. Vrbenský quarry before reclamation [9].

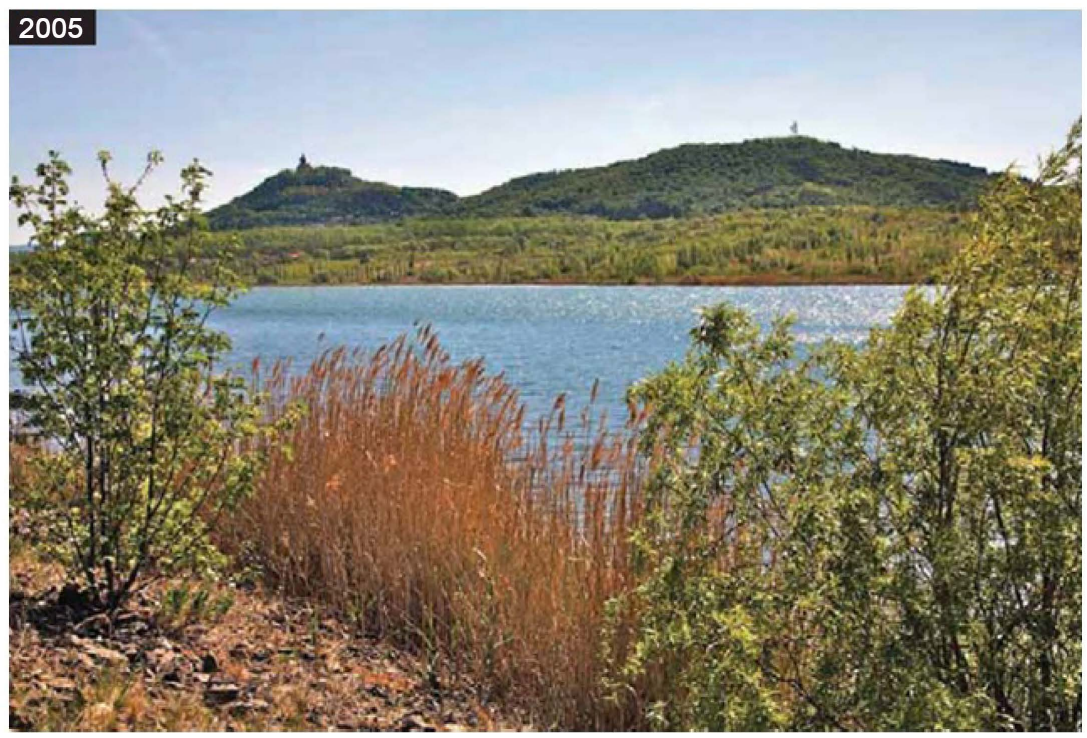

Figure 10. Lake Matylda after the hydrological recultivation of Vrbenský quarry [9]. 


\section{Conclusions}

Sustainable development is a frequently mentioned concept in all branches within the framework of managing the state and developing society. This article was prepared as part of the project "Sustainable Forms of Management in Anthropologically Affected Areas", which focuses on regions damaged by the mining of brown coal in North Bohemia and on its subsequent renewal within the framework of recultivation and revitalization. In this regard, it is very important to ensure the development of the landscape in a permanently sustainable way in order to provide the right conditions for future generations.

In order to promote an environmental policy, it is necessary to apply direct and indirect tools rationally and effectively and likewise adhere to the principles of sustainable development. Development has to support harmony between people and nature, life within the limits of the capacity of the biosphere, perhaps ensure equality in the distribution of property, or in also satisfying the needs of other living creatures. The TUR strategic documents in the Czech Republic specify procedures and processes that help in sustaining the proper development of our society.

A good environment is the basic condition for the existence of life on Earth in any form. Humankind intervenes in the environment with activities associated with securing their everyday existence, particularly industrial and agricultural production, transportation and energy, and these interventions are mostly negative where they are connected with the production of emissions, wastewater, various waste products, deforestation, land-grabbing, etc. These negative impacts cannot occur, however, without limitations, and so there exist boundaries that must be respected.

\section{Acknowledgements}

This article was supported by the project QJ1520307 entitled "Sustainable Forms of Management in Anthropologically Affected Areas". This project was carried out with financial support from the state budget through the KUS program, Ministry of Agriculture of the Czech Republic.

\section{References}

[1] Czech Coal Group (2015) Map of the Deposits of Brown Coal and Lignite in the Czech Republic. http://www.czechcoal.cz/cz/profil/ccg/rz/index.html

[2] Demo, M., Bielek, P. and Hronec, O. (1999) Sustainable Development. Slovak University of Agriculture, Nitra. Research Institute of Soil Sciences and Soil Protection, Bratislava.

[3] United Nations Development Programme (2015) UN Summit on Worldwide Sustainable Development, New York.

http://www.undp.org/content/undp/en/home/sdgoverview/post-2015-development-agenda .html

[4] Klinda, J. (2001) Slovak Environmental Policy: Inseparable Part of the European Environmental Policy, Slovakia.

[5] Klinda, J. (2000) Glossary of Environmentalism. Ministry of the Environment SR, Bratislava. 
[6] Vrablikova, J., Vrablik, P. and Zoubkova, L. (2014) Creating and Protecting the Landscape. Faculty of Environment, University of J. E. Purkyně in Ust nad Labem, Czech Republic.

[7] Czech State Administration of Land Surveying and Cadastre (2015) Summaries of Land Resources from the Cadastral Data of the Czech Republic 1967-2015, Prague.

http://www.cuzk.cz/en

[8] Vrablikova, J., et al. (2011) Land Revitalization of North Bohemia. Faculty of Environment, University of J. E. Purkyne in Ustí nad Labem, Czech Republic.

[9] Štýs, S., Bízkova, R. and Ritschelova, I. (2014) Transformations of the Northwest. Czech Statistical Office, Prague.

\section{Submit or recommend next manuscript to SCIRP and we will provide best service} for you:

Accepting pre-submission inquiries through Email, Facebook, LinkedIn, Twitter, etc. A wide selection of journals (inclusive of 9 subjects, more than 200 journals)

Providing 24-hour high-quality service

User-friendly online submission system

Fair and swift peer-review system

Efficient typesetting and proofreading procedure

Display of the result of downloads and visits, as well as the number of cited articles

Maximum dissemination of your research work

Submit your manuscript at: http://papersubmission.scirp.org/

Or contact jep@scirp.org 